\title{
Anticoccidial efficacy of drinking water soluble diclazuril in the control of Eimeria acervulina oocysts on experimentally-infected broiler chickens
}

\author{
[Eficiência do diclazuril (formulação líquida) no controle de oocistos de Eimeria acervulina em frangos de corte \\ experimentalmente infectados] \\ R.C.L. Assis ${ }^{1}$, M.C. Cury $^{1}$, F.D. Luns $^{2}$, R.L. Assis $^{3}$ \\ ${ }^{1}$ Universidade Federal de Uberlândia - Instituto de Ciências Biológicas - Uberlandia, MG \\ ${ }^{2}$ Veterinário autônomo \\ ${ }^{3}$ Universidade Federal de Minas Gerais - Instituto de Ciências Biológicas - Belo Horizonte, MG
}

\begin{abstract}
The experiment was carried out with 150 Cobb broiler chickens divided into 3 groups with 50 birds each. The groups of infected chickens orally received $1 \mathrm{ml}$ of inoculum containing $3 \times 10^{3}$ Eimeria acervulina sporulated oocysts at 12 days of age. Group 1 was kept as a positive control with infected non-medicated birds, group 2 was medicated with diclazuril $(1 \%)$ with a dose of $1 \mathrm{~mL} / 4 \mathrm{~L}$ of drinking water for 2 successive days, 5 days after infection, while group 3 was kept as negative control with non-infected and non-medicated birds. Oocysts count per gram of feces, score of macroscopic intestinal lesions and weight gain were evaluated. The group treated with diclazuril showed significant and satisfactory improvement in the assessment criteria when compared to the infected non-medicated group. The results revealed more reduction in the total oocyst count and intestinal lesion score in the medicated than in the infected nontreated group. The results confirmed that (1\%) liquid diclazuril is effective to control Eimeria infection.
\end{abstract}

Keywords: Eimeria acervulina, broilers, coccidiosis, diclazuril

\section{RESUMO}

O experimento foi realizado com 150 frangos de corte da linhagem Cobb, divididos em 3 grupos de 50 aves cada. Os frangos de dois grupos (G1 e G2) receberam, por via oral, $1 \mathrm{~mL}$ de inóculo contendo $3 \times 10^{3}$ oocistos de Eimeria acervulina aos 12 dias de idade. O grupo 1 foi mantido como grupo controle positivo (infectado não medicado), o grupo 2 foi medicado com diclazuril (1\%) na dose de $1 \mathrm{~mL} / 4$ litros de água potável por dois dias sucessivos, cinco dias após a infecção. Um terceiro grupo (G3) foi mantido como controle negativo não infectado e não medicado. O número de oocistos por grama de fezes $(O O P G)$, o escore de lesões macroscópicas intestinais e o ganho de peso corporal foram avaliados. No G1, o OOPG foi de $3,67 \times 10^{6}$ e o peso final foi de $1,392 \mathrm{~kg}$, valores significativamente diferentes do OOPG de $1,93 \times 10^{6}$ oocistos e do peso final de $1,613 \mathrm{~kg}$ do $\mathrm{G} 2$ (diclazuril). Os resultados provaram que o diclazuril (1\%) em formulação líquida e na dosagem de $1 \mathrm{~mL} / 4$ litros de água por dois dias sucessivos foi eficaz no controle de Eimeria acervulina.

Palavras-chave: Eimeria acervulina, frangos de corte, coccidiose, diclazuril

\section{INTRODUCTION}

Coccidiosis is a parasitic disease that causes the greatest economic losses to the poultry industry worldwide, which were estimated at $\$ 3$ billion dollars annually (Dalloul and Lillehoj, 2006). Seven species of Eimeria are known to infect

Recebido em 6 de junho de 2011

Aceito em 20 de julho de 2012

E-mail: rafaela.carolina@ufv.br broilers and four species of economic importance were described in Brazil: Eimeria acervulina, E. maxima, E. tenella and E. necatrix (McDougald et al., 1987). Eimeria acervulina has proven prevalence in broilers worldwide, is widely distributed in Brazil, and is of unnoticed subclinical evolution and economic importance (Kawazoe et al., 2005). 
The usual strategy to control coccidiosis in broilers is based on the use of anticoccidial drugs (Conway and Mckenzie, 1991). The prophylactic anticoccidial efficacy of diclazuril in feed was extensively studied in chickens (Conway et al., 2002; Awaad et al., 2003).

New formulations of water soluble diclazuril for administration in drinking water were introduced in many parts of the world, and few studies were conducted to study its efficacy in the prevention and control of chicken coccidiosis (El-Banna et $a l ., 2005)$. The aim of this study was to evaluate the efficacy of a soluble formulation of diclazuril in the control of E. acervulina oocysts administered for only two days. This single experiment with the soluble form of diclazuril might be useful for broiler producers where the feed treatment is difficult or not possible.

\section{MATERIALS AND METHODS}

One hundred-fifty one-day-old female, coccidiosis-free, Cobb chicks, initial weight 0.09 pounds, obtained from Globo Aves Company, Brazil, were divided into three groups and given feed and water ad libidum without any additives or anticoccidial drugs. This experimental study was approved by the Animal Ethics Committee (CEUA), Federal University of Uberlândia; protocol number 050/2008.

Eimeria acervulina, strain Ea3LP8a, was provided by Empresa Brasileira de Pesquisa Agropecuária (EMBRAPA), Santa Catarina, Brazil. The inoculum purification used in this study was performed by the Technical Centre for Eimerias Reprodution, by BIOVET Animal Health Laboratory, located in São Paulo, Brazil. BIOVET provided the 12-day-old broilers individually inoculated with oral doses of $3 \times 10^{3}$ E. acervulina oocysts, strain Ea3LP8a (EMBRAPA), in a volume of $0.5 \mathrm{~mL}$ of inoculum per bird using a $1 \mathrm{~mL}$ sterile syringe coupled to a cannula to access the esophagus.

Water-soluble anticoccidian Diclazuril at $1 \%$ concentration (Ventaco Laboratory, Brazil) was administrated as $1 \mathrm{~mL} / 4 \mathrm{~L}$ for 2 successive days, 5 days after infection.

Sample feces of each group were collected daily to determine the prepatent period, curve of oocyst elimination and to test the drug's curative efficacy. Feces were collected one day before the inoculation and then daily until the end of the experimental period $[23$ days after infection (AI), 35 day-old-chickens]. The number of oocysts/gram of feces for each group was calculated using the following method: $1 \mathrm{~g}$ of faeces was homogenized in $100 \mathrm{~mL}$ water and passed through a cheesecloth folded four times (placed over a sieve). Then after another homogenization cycle, $10 \mathrm{~mL}$ of the suspension was removed and centrifuged. The pellet was resuspended in a saturated sugar solution and centrifuged. The tube was then filled with the same solution to form a meniscus. A coverslip was placed over the meniscus which, after 15 minutes, was transferred onto a clean slide for oocyst count. The slides were examined in all their extension, where all oocysts observed were counted. The total number of oocysts was converted to total volume of $1 \mathrm{~g}$ previously diluted by multiplying by 10 to obtain the number of oocysts per gram of feces.

Broilers in each group were weighted weekly from 1 to 35 days of age. The mean body weight gain was calculated. The consumption was measured to determine the feed conversion ratio.

At necropsy, the intestines were submitted to macroscopic evaluation of lesions. Small intestine lesions were scored on a scale according to severity (Johnson and Reid, 1970).

A total of 150 birds were divided into three groups (G1, G2 and G3), each consisting of 50 birds. Group 1 (G1) was kept as a positive infected, non-medicated control; group 2 (G2) was medicated with $1 \%$ water soluble Diclazuril in a dose of $1 \mathrm{~mL} / 4 \mathrm{~L}$ of drinking water for 2 successive days, 5 days after infection (Amer et al., 2007); and group 3 (G3) was kept as a negative, non-infected, non-medicated control. Both (G1) and (G2) were orally inoculated with $1 \mathrm{~mL}$ solution containing sporulated oocysts of $E$. acervulina at 12 days of age. In the study, feces samples were collected daily for oocyst count (OOPG). The average weight gain at the end of the observation period was calculated. Ten broilers from each group were euthanized and five segments of $4.5 \mathrm{~cm}$ of the small intestine were macroscopically examined for lesion-score evaluation.

The data was transformed into logarithmic scale (log-10) and submitted to the Tukey test at $5 \%$ 
level of significance $(\mathrm{P} \leq 0.05)$ for comparison of quantitative variables.

\section{RESULTS}

The prepatent period observed in this study was of 120 hours (five days). There were increasing values of oocysts in the feces from the day 5 to day 7 AI, with a peak of primary disposal at day $7 \mathrm{AI}$ and secondary peaks at day 13 and day 15 AI. There was a progressive decrease in the number of oocysts eliminated in the feces. The broilers treated with Diclazuril at 17 days of age (G2) showed a particular elimination curve. The curve obtained before the treatment was similar to the positive control (G1) and, after the use of the coccidiostatic, there was a significant reduction $(\mathrm{p} \leq 0.05)$ in the mean of eliminated oocysts (Figure 1).

Table 1 shows that water soluble diclazuril induced a significant reduction in the mean of oocyst shedding compared with the infected nonmedicated positive control group $(\mathrm{p} \leq 0.05)$.

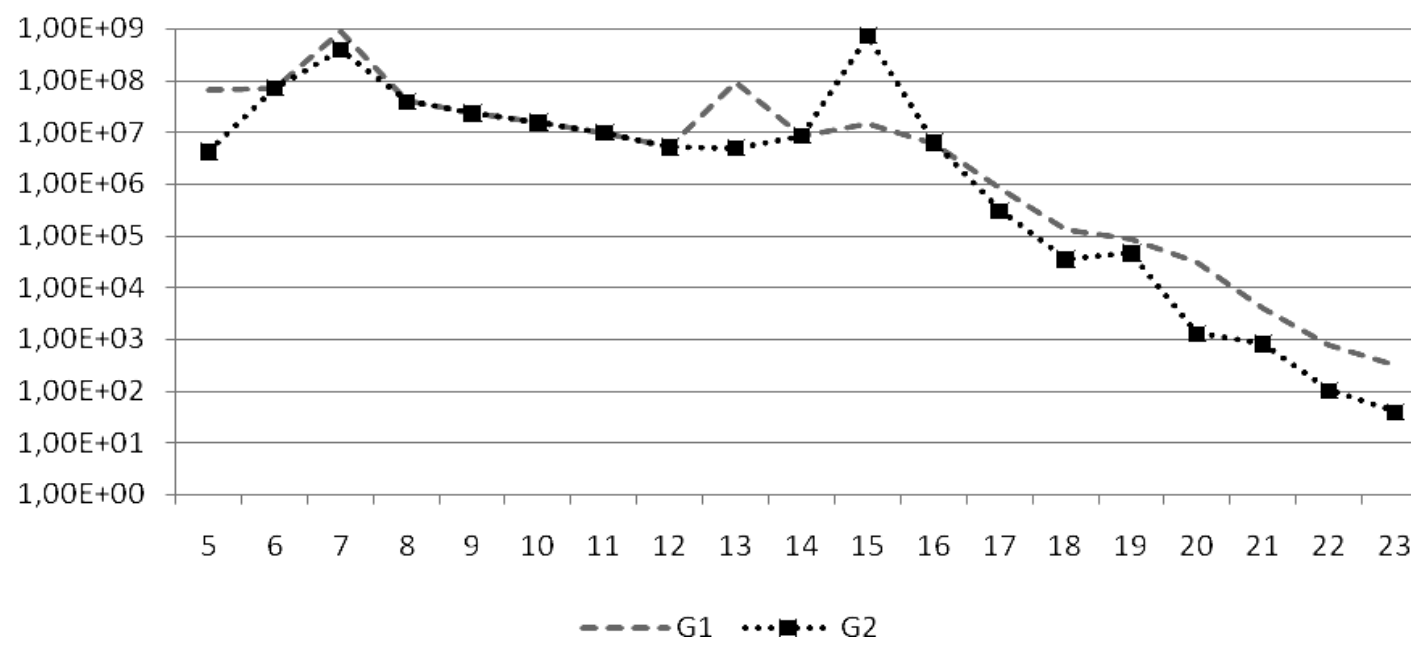

(Note: $\mathrm{Y}$ axis $=$ mean oocyst logarithmic scale and $\mathrm{X}$ axis $=$ days after infection $)$.

Figure 1. Daily elimination curve of recovered oocysts from feces of broilers infected with Eimeria acervulina; Group 1 (G1): positive control, Group 2 (G2): Diclazuril treated birds.

Table 1. Means of oocysts recovered from feces (standard deviation) and elimination peaks observed in broiler chickens infected with Eimeria acervulina

\begin{tabular}{|c|c|c|c|}
\hline \multirow[b]{2}{*}{ Treatment } & \multirow{2}{*}{$\begin{array}{l}\text { Mean of oocysts } \\
\text { recovered from feces } \\
(\mathrm{SD})\end{array}$} & \multicolumn{2}{|c|}{ Elimination peaks } \\
\hline & & $\begin{array}{c}\text { Primary peak } \\
\text { (Day } 7 \text { AI) }\end{array}$ & $\begin{array}{c}\text { Secondary peak } \\
\text { (Day } 15 \mathrm{AI} \text { ) }\end{array}$ \\
\hline G1 Positive control & $3.67 \times 10^{6}\left(8.96 \times 10^{3}\right) a$ & $8.43 \times 10^{6}$ & $4.03 \times 10^{6}$ \\
\hline G2 Diclazuril & $1.93 \times 10^{6}\left(6.70 \times 10^{3}\right) b$ & $6.68 \times 10^{6}$ & $3.17 \times 10^{6}$ \\
\hline
\end{tabular}

Means followed by different small letters in the same column are significantly different by the Tukey test $(\mathrm{P} \leq 0.05)$.

Performance values are presented in Table 2. Inoculated, non-medicated chickens (G1) showed the worst performance, with lower weight at 35 days of age $(1.392 \mathrm{~kg} \pm 41.9$ grams $)$ and higher feed conversion ratio. In all groups, the most prominent clinical signs were diarrhea after 17 days of age.
Table 3 shows the mean weekly weights taken at $7,14,21,28$ and 35 days of age and the significant difference $(\mathrm{P} \leq 0.05)$ in weights of the first two weeks ( 7 and 14 days) between the G1 and $\mathrm{G} 3$ groups. 
Table 2. Average values: final weight (FW) (35 days) and feed conversion ratio (FCR) in broiler chickens experimentally infected with Eimeria acervulina (G1 and G2) and negative control (G3), calculated at the end of experimental period

\begin{tabular}{lcc}
\hline Treatment & FW $(\mathrm{kg})$ & FCR $(\mathrm{kg})$ \\
\hline G1 Positive control & $1.392 \pm 0.0419 \mathrm{a}$ & $1.917 \mathrm{c}$ \\
G2 Diclazuril & $1.613 \pm 0.0810 \mathrm{~b}$ & $1.834 \mathrm{~b}$ \\
G3 Negative control & $1.599 \pm 0.0510 \mathrm{~b}$ & $1.692 \mathrm{a}$ \\
\hline
\end{tabular}

Means followed by different small letters in the same column are significantly different by the Tukey test $(\mathrm{P} \leq 0.05)$. Measure unit: kilograms (kg).

Table 3. Weekly mean weights in broiler chickens experimentally infected with Eimeria acervulina (G1 and G2) and negative control (G3)

\begin{tabular}{lccccc}
\hline \multirow{2}{*}{ Treatment } & \multicolumn{5}{c}{ Days } \\
\cline { 2 - 6 } & 7 & 14 & 21 & 28 & 35 \\
\hline G1 Positive control & $142 \pm 8.7 \mathrm{a}$ & $380 \pm 12.3 \mathrm{a}$ & $647 \pm 27.6 \mathrm{a}$ & $1,090 \pm 51.4 \mathrm{a}$ & $1,392 \pm 41.9 \mathrm{a}$ \\
G2 Diclazuril & $176 \pm 3.9 \mathrm{~b}$ & $445 \pm 10.4 \mathrm{~b}$ & $725 \pm 18.7 \mathrm{~b}$ & $1,274 \pm 43.7 \mathrm{~b}$ & $1,587 \pm 63.4 \mathrm{~b}$ \\
G3 Negative control & $182 \pm 7.6 \mathrm{~b}$ & $452 \pm 14.3 \mathrm{~b}$ & $710 \pm 22.8 \mathrm{~b}$ & $1,250 \pm 41.3 \mathrm{~b}$ & $1,599 \pm 51.0 \mathrm{~b}$ \\
\hline
\end{tabular}

Means followed by different small letters in the same column are significantly different by the Tukey test $(\mathrm{P}<0.05)$. Measure unit: grams (g).

In $\mathrm{G} 2$ birds the drug induced a significant improvement in the mean body weight gain at the end of the observation period in comparison with the infected, non-medicated group. From day 21, there was a significant weight improvement in chickens treated with Diclazuril $(\mathrm{P} \leq 0.05)$. The chickens in this group had compensatory weight gain after the treatment, although the feed conversion ratio was impaired, with high values of feed intake. Based on Table 3 , the body weights in the diclazuril-treated group were significantly higher when compared to the Eimeria-infected, non-medicated control group. In addition, there was no difference between the non-infected control and the diclazuril-treated group.

Table 4 shows that the mean scores of gross lesions for Group 1 were $3.5 \pm 0.53$. This was the group with the greatest injury severity and the number of recovered oocysts from feces (OOPG) showed a direct correlation with the macroscopic lesion scores $(\mathrm{P} \leq 0.01)$.

Table 4. Eimeria acervulina oocyst counts and macroscopic lesion scores in necropsied broilers at 21 days of age

\begin{tabular}{lccc}
\multirow{2}{*}{ Treatment } & \multicolumn{2}{c}{ Comparison between OOPG and macroscopic lesion score } \\
\cline { 2 - 4 } & OOPG & $\begin{array}{c}\text { Macroscopic lesion } \\
\text { score }\end{array}$ & $\mathrm{r}$ \\
\hline G1 Positive control & $3.67 \times 10^{6}\left(8.96 \times 10^{3}\right) \mathrm{c}$ & $3.5 \pm 0.53 \mathrm{~b}$ & +0.74 \\
G2 Diclazuril & $1.93 \times 10^{6}\left(6,70 \times 10^{3}\right) \mathrm{b}$ & $1.6 \pm 0.69 \mathrm{a}$ & +0.65 \\
G3 Negative control & 0a & $0 \mathrm{a}$ & 0 \\
\hline
\end{tabular}

Means followed by different small letters in the same column are significantly different by the Tukey and KruskalWallis tests $(\mathrm{P} \leq 0.05)$. Pearson's correlation test $(\mathrm{P} \leq 0.01)$.

\section{DISCUSSION}

The prepatent period observed in this study was similar to that described by Gabriel et al. (2006) and Zulpo et al. (2007). Prepatent periods ranging between 97 and 120 hours are commonly reported in $E$. acervulina infection, with variations according to the strain studied (Conway and Mckenzie, 1991). The kinetics of oocyst elimination of strain Ea3LP8a was characteristic of the parasite biological cycle. The initial phase is consistent with the growing number of Eimeria sp. and release of oocysts by intestinal cell disruption (Kawazoe et al., 2005). The secondary elimination peak occurred due to the reinfection with oocysts present on floor litter. A secondary peak of oocysts, with subsequent significant decrease in elimination, was also reported by other authors (Guzman et al., 2003; Kawazoe et al., 2005). The decrease in 
elimination primarily from the third week may indicate the cell immunity performance against the parasite. According to Lillehoj and Lillehoj (2000), immunity against Eimeria sp. is established by continuous reinfection of oocysts, until reaching subclinical levels.

The elimination curve of the chickens treated with Diclazuril (G2) showed the efficiency of anticoccidian against strain Ea3LP8a of $E$. acervulina. Daugschies et al. (2002) reported this drug effectiveness in all Eimeria sp life cycle periods. The oocyst mean elimination and the broilers' weight performance are safer parameters of infection to measure the effect of coccidiosis. In this study, a decrease in broiler performance due to infection can be observed. Chickens with coccidiosis have reduced the weight gain. Worsening of feed conversion occurs because intestine epithelial cells are damaged by infection, impairing nutrient digestion and absorption at the duodenum (Allen and Feterrer, 2002).

Clinical signs such as diarrhea and weight loss were observed in this study. The beginning of clinical symptoms and macroscopic lesions in the intestine of a bird infected with Eimeria sp. depends on the intake of sporulated oocysts, the location of the parasite in the villi and the host immune response (Guzman et al., 2003). The decrease in oocyst reduces the severity of intestine lesions and, therefore, the signs. This may explain the reduction in injury severity and performance observed in the treated group (G2) compared to the positive control (G1). Persia et al. (2006) reported a positive correlation between OOPG and macroscopic lesion scores, corroborating with the findings of this study. These results agree with those reported by ElBanna et al., (2005) who reported that diclazuril in the drinking water was appropriate for use in the prevention of Eimeria infection and treatment in chickens as indicated by the decreased oocyst number and lesion score of the treated groups. In addition, Qi (1999) demonstrated that diclazuril in concentrations of $0.25,0.5$ or $1 \mathrm{~mL} / \mathrm{L}$ in the drinking water of E. tenella infected chickens, caused increase in body weight, decrease in losses by infection and increased index of resistance to the infection with the increasing rate of diclazuril. Results of the field study proved that two days water medication with diclazuril improved the total oocyst count and the lesion score compared with the nonmedicated group infected with Eimeria acervulina.

\section{CONCLUSION}

In this study, the efficiency of Diclazuril in drinking water for only 2 successive days at the 5 th day post infection as a method of controlling avian coccidiosis was confirmed by the reduced number of oocysts recovered from feces, the lower macroscopic lesion score and the improved performance of chickens.

\section{REFERENCES}

ALLEN, P.C.; FETTERER, R.H. Recent advances in biology and immunobiology of Eimeria species and in diagnosis and control of infection with these coccidian parasites of poultry. Clin. Microbiol. Rev., v.15, p.58-65, 2002.

AMER, M.M.; EL-GHANY, W.A.A.; AMER, A.M. et al. The efficacy of diclazuril (liquid formulation) in the prevention and control of coccidiosis in broiler chicken. Vet. Med. J., p.96101, 2007.

AWAAD, M.H.; MANAL, A.A.; SAHAR, A.Z.; HILALI, M.A. Anticoccidial efficacy of steroidal sapogenins (organic coccidiostate) in broiler chickens (semi field and field trials). Vet. Med. Soc. Parasitol. J., v.1, p.123-136, 2003.

CONWAY, D.P.; MCKENZIE, E. (Ed.) Poultry Coccidiosis: diagnostic and testing procedures Manual. New York: Pfizer, 1991. 63p.

CONWAY, D.P.; MATHIS, G.F.; LANG, M. The use of diclazuril in extended with drawal anticoccidial programmes: Efficacy against Eimeria spp. in broiler chickens in floor pens. Poultry Sci., v.81, p.349-352, 2002.

DALLOUL, A.A.; LILLEHOJ, H.S. Avian Coccidiosis: recent advancements in control measures and vaccine development. Exp. Rev. Vac., v.5, p.143-163, 2006.

DAUGSCHIES, A.; BOSE, R.; MARX, J. et al. Development and application of a standardized assay for chemical disinfection of coccidian oocysts. Vet. Parasitol., v.103, p.299-308, 2002. 
EL-BANNA, H.A.; EL-BAHY, M.M.; ELZORBA, H. et al. Anticoccidial efficacy of drinking water soluble diclazuril on experimental and field coccidiosis in broiler chickens. J. Vet. Med., v.52, p.287-291, 2005.

GABRIEL, L.; MALLET, S.; LECONTE, M. et al. Effects of whole wheat feeding on the development of coccidial infection in broiler chickens until market-age. Anim. Feed Sci. Technol., v.129, p.279-303, 2006.

GUZMAN, V.B.; SILVA, D.A.; KAWAZOE, U. et al. A comparison between IgG antibodies against Eimeria acervulina, E. maxima e E. tenella and oocyst shedding in broiler-breeders vaccinated with live anticoccidial vacines. Vaccine, v.21, p.4225-4233, 2003.

JOHNSON, J.; REID, W.M. Anticcocidial drugs: lesion scoring techniques in battery and floor-pen experiments with chickens. Exp. Parasitol., v.28, p.30-36, 1970.

KAWAZOE, U.; BORDIN, E.L.; LIMA, C.A. et al. Characterization and histopathological observations of a selected Brazilian precocious line of Eimeria acervulina. Vet. Parasitol., v.131, p.5-14, 2005.
LILLEHOJ, E.P.; LILLEHOJ, H.S. Avian coccidiosis. A review of acquired intestinal immunity and vaccination strategies. Avian Dis., v.44, p.408-425, 2000.

McDOUGALD, L.R.; SILVA, J.M.L.; SOLIS, J. et al. A survey of sensitivity to anticoccidial drugs in 60 isolates of coccidia from broiler chickens in Brazil and Argentina. Avian Dis., v.31, p.287-292, 1987.

PERSIA, M.E.; YOUNG, E.L.; UTTERBACK, P.L. et al. Effects of dietary ingredients and Eimeria acervulina infection on chick performance: apparent metabolizable energy and aminoacid digestibility. Poultry Sci., v.85, p.4855, 2006.

QI, J.Z. Study of the efficacy of diclazuril solution in Eimeria tenella inoculated chicks. Zhej. Non. Kexue. v.1, p.44-46, 1999.

ZULPO, D.L.; PERETTI, J.; ONO, L.M. et al. Pathogenicity and Histopathological observations of commercial broiler chicks experimentally infected with isolates of Eimeria tenella, E. acervulina and E. maxima. Cienc. Agrárias, v.28, p.97-104, 2007. 